\title{
Breeding and trade of wildlife in Santa Catarina state, Brazil
}

\author{
Kuhnen, VV. ${ }^{a *}$, Remor, JO. ${ }^{b}$ and Lima, REM. ${ }^{b}$ \\ aDepartamento de Ecologia e Zoologia, Laboratório de Etologia Aplicada, \\ Universidade Federal de Santa Catarina - UFSC, Campus Universitário, Trindade, CEP 88010-970, Florianópolis, Brazil \\ ${ }^{\mathrm{b} C}$ Curso de Ciências Biológicas, Universidade Federal de Santa Catarina - UFSC, \\ Campus Universitário, Trindade, CEP 88010-970, Florianópolis, Brazil \\ *e-mail: vanessavk@ig.com.br \\ Received November 16, 2010 - Accepted March 22, 2011 - Distributed February 29, 2012
}

(With 2 figures)

\begin{abstract}
The wildlife trade is becoming increasingly more relevant in discussions concerning conservation biology and the sustainable management of natural resources. The aim of this study was to document the trade and breeding of wildlife in Santa Catarina state, in southern Brazil. Data was collected from annual reports (1996-2008) of wildlife breeders which were sent to IBAMA. By the end of 2008, there were 79 wildlife breeders and 11 wildlife traders distributed in Santa Catarina. Commercial breeding accounted for the highest number of breeders (51\%). In total, there are 213 species of wild animals bred in the state: 177 birds, 19 mammals and 17 reptiles. Of these, $48 \%$ are native to Santa Catarina, $32 \%$ occur in other Brazilian states and 20\% are exotic to Brazil. Nine percent of the species bred are vulnerable or endangered. It was observed that some breeders reported breeding unauthorized species. Altogether, 93 species are bred illegally by 19 breeders. Of these species, 48 are native to Santa Catarina and three are classified as vulnerable or in danger of extinction. We hope the data presented in this paper contributes to the development of conservation strategies and conscious use of wildlife resources in Brazil.
\end{abstract}

Keywords: legal breeding, pet trade, conservation, endangered species.

\section{Criação e comercialização de animais silvestres no estado de Santa Catarina, Brasil}

\begin{abstract}
Resumo
O comércio de animais silvestres está se tornando cada vez mais relevante em discussões sobre conservação e manejo sustentável de recursos naturais. O objetivo do presente estudo foi documentar esse comércio e a reprodução de animais silvestres no Estado de Santa Catarina. Os dados deste trabalho foram coletados de relatórios encaminhados anualmente ao IBAMA (1996-2008). Ao final de 2008, existiam 79 criatórios e 11 comerciantes de fauna em Santa Catarina. A criação comercial é a categoria com maior número de criatórios (51\%). Ao todo, são criadas 213 espécies de animais silvestres no Estado, sendo 177 aves, 19 mamíferos e 17 répteis. Destas, 48\% possuem distribuição original para Santa Catarina, 32\% ocorrem em outros Estados brasileiros e 20\% são exóticas do Brasil. Nove por cento das espécies criadas estão vulneráveis ou ameaçadas de extinção. Foi observado que alguns criatórios relatavam a criação de espécies não autorizadas. Ao todo, 93 espécies são criadas ilegalmente em 19 criatórios. Das espécies criadas ilegalmente, 48 possuem distribuição original para Santa Catarina e, destas, três estão classificadas como vulneráveis ou ameaçadas de extinção. O presente trabalho poderá subsidiar o desenvolvimento de estratégias de conservação e uso consciente dos recursos da fauna silvestre brasileira.
\end{abstract}

Palavras-chave: criação legal, comércio de animais de estimação, conservação, espécies ameaçadas.

\section{Introduction}

People have kept wild animals as pets for centuries. It is currently one of the most popular hobbies in the world and the demand is increasing every year (Carrete and Tella, 2008). Birds are the most desired pets among wildlife species, with over one million exotic birds legally traded around the world on an annual basis (Gilardi, 2006). Trade in wildlife resources, especially by unsustainable forms of exploitation, has been a relevant cause of biodiversity loss.

According to the latest report from the Brazilian Network for Combating Wildlife Trafficking (RENCTAS, 2001) about 38 million specimens are illegally captured from the wild in Brazil annually. However, the number of animals traded is much smaller due to losses that occur throughout the process. It is estimated that in Brazil, for every 10 animals illegally caught in the wild, only one survives (RENCTAS, 2001). In order to protect Brazilian 
biodiversity, wildlife has been regulated since 1967 , legalizing only breeding and trading of specimens born in captivity (Law n ${ }^{\circ} 5197 / 67$ ).

The use and management of fauna is regulated by the Normative Instruction (NI) $\mathrm{n}^{\circ} 169 / 08$; ideally as a way of combining the many existing rules set in place previously. This Normative Instruction came about by Resolution $n^{\circ} 394 / 07$ of the Brazilian National Council on the Environment (CONAMA), which states that the Brazilian Institute of Environment (IBAMA) must publish an up-to-date list of wild species every two years which allows breeding and trade in Brazil. However, so far this list has not been published.

The market of legalized wildlife products is divided into four distinct sectors: handicrafts (e.g. jewelry accessories and household decoration), pets, replacement of breeding pairs in legal pet trade, and products for human consumption. The trade of live animals and animal parts or products is only legal when they are purchased from licensed breeders and sold in establishments which are registered as "wildlife traders". This category is regulated by the IBAMA NI n ${ }^{\circ} 117 / 97$.

The four breeding categories of wildlife stated in IBAMA NI $n^{\circ} 169 / 08$ are: scientific breeding of wildlife for research; scientific breeding of wildlife for conservation purposes; commercial breeding of wildlife (for the pet industry); and amateur songbird breeding. The commercial category is the only one authorized to sell specimens bred in captivity. Prior to IBAMA NI $n^{\circ} 169 / 08$, each category of breeding was ruled by a special ordinance and there were four categories of breeders: commercial, scientific, conservationist and amateur.

The IBAMA NI $n^{\circ} 169 / 08$, in addition to regulating the use and management of wildlife, proposes an electronic management system of wildlife. In 2008, IBAMA began implementing the Brazilian National System of Fauna Management (Sisfauna). Sisfauna is a computerized system developed to record and control wildlife breeders and their breeding stock. By using this system, authorizations and licenses can be obtained, and eventually it will be possible to control breeding stock and record transactions, among other functions. The aim of Sisfauna is to combat against illegal activities related to wildlife, as well as create an online database of information which will help the government supervise and manage wildlife breeding in Brazil.

Wildlife breeding, especially that of songbirds, is a cultural tradition preserved in different regions of the country. However, obtaining a legal specimen has a high cost, which encourages wildlife trafficking. Currently, about $90 \%$ of the wildlife trade in Brazil is illegal (RENCTAS, 2002), and the demand for wildlife as pets encourages trafficking of wild animals in the country (RENCTAS, 2001).

Due to the reality of wildlife trafficking in Brazil, the legalization of breeding wild animals in captivity is a controversial topic that has been discussed by opposing currents. On one hand are those who defend that legalized breeding is a tool to combat trafficking, while on the other hand are those who argue that, due to the fragility of governmental control agencies, the legalized breeders end up effectively participating in illicit trading. Legalized breeders who want to increase and diversify their breeding stock and their sales are among the main customers of the illegal wildlife trade, participating not only in the purchase of specimens of illegal origin, but also illegally selling them using false invoices (Gonçalves and Regalado, 2007).

In Brazil, most of the wildlife that is illegally traded are caught in the North, Northeast and Midwest regions and are transported to the South and Southeast regions by federal highways (RENCTAS, 2001). In the South, Santa Catarina has the least amount of information available about wildlife trafficking and the vulnerability status of their local fauna, given that no list of threatened species for the state has ever been published.

The wildlife trade is becoming a matter which is increasingly more relevant to discussions on conservation biology and the sustainable management of natural resources. However the magnitude of the breeding and trade of wildlife in Brazil, especially in Santa Catarina state, has not been thoroughly investigated and, as such, is poorly understood. The lack of information about the wildlife trade makes it difficult to evaluate its magnitude and impact on the environment. Wildlife breeding data in Santa Catarina is almost absent, restricted only to the lists of breeders available on the website of IBAMA (2003, 2004a,b). However those lists are outdated by four to seven years, depending on the breeding category.

Given this information, conservation strategies should be as well informed as possible by empirical and theoretical evidence. Thus, the aim of our study was to create the first database of legal wildlife breeders and sellers in Santa Catarina state. The first license in the state was issued in 1996 and thus data records include 1996-2008. This research describes in detail the main orders, families and species which were being bred and traded in the state, the number of exotic species and the number of those which are endangered according to the IUCN Red List categories and criteria (IUCN, 2009). We also present an analysis of the potential increase in the number and diversity of species bred throughout the state.

\section{Material and Methods}

\subsection{Study area}

Santa Catarina state is in the southern region of Brazil and its neighboring states include Paraná and Rio Grande do Sul. The western region of the state is also limited by Argentina. Santa Catarina is the twentieth largest Brazilian state at $95,346.181 \mathrm{~km}^{2}$. The state has a population of approximately six million inhabitants distributed in 293 municipalities, and Florianópolis ( $27^{\circ} 35^{\prime} 49^{\prime}$ ' $\mathrm{S}$ and $48^{\circ} 32^{\prime} 56^{\prime \prime} \mathrm{W}$ ) is the state capital. Santa Catarina is the seventh richest state in Brazil and its gross domestic product amounts to $4 \%$ of the national total (IBGE, 2007). The main economic activities are agriculture, livestock, fisheries, tourism and industry. 
The climate in Santa Catarina is subtropical-humid following the Köppen climate classification ( $C f a$ and $C f b$ ) with well-defined seasons. Average temperatures range from 13 to $25^{\circ} \mathrm{C}$ and are lower in the uplands. Rainfall is well-distributed during the year, averaging $1500 \mathrm{~mm}$ annually. The state includes areas of Atlantic Forest and is covered by four major vegetation types: Dense Rain Forest, Araucaria Forest, Alpine Grassland, Deciduous Forest, and Coastal Vegetation (Klein, 1978).

Santa Catarina is subdivided into geographic regions known as meso-regions which comprise the major regions of the state, united by their geography, demographic and cultural characteristics. Currently there are six meso-regions in Santa Catarina: Great Florianópolis, Itajaí Valley, North, West, Sierra and South. The most populous regions are the Itajaí Valley and Great Florianópolis.

\subsection{Data collection}

The database in this study was obtained from an analysis of the licensing files of wildlife breeders and traders from the IBAMA Wildlife Center of Santa Catarina state (NUFAU). We analyzed all cases licensed until December 2008.

The information in each analyzed file was catalogued generating a data sheet with: a) name of the breeder, b) municipality location, c) license date, d) species authorized by the breeding license, and e) species bred. Information on the species kept by each breeder was obtained from annual reports submitted to NUFAU. From these data, it was possible to determine which species, in each class, are the most bred for each category of breeders. By comparing the number of species currently bred with the number of all authorized species, the possible increase in the number of species bred in the state could be estimated. The classification category of the breeder followed the legislation at the time of the license.

To identify the conservation status of the bird species traded in the state, each species was classified following the IUCN (International Union for Conservation of Nature) criteria, version 3.1 (IUCN, 2009). The geographical distribution of the traded birds was also searched to obtain the proportion of species from Santa Catarina that was traded in the state (Sick, 1997; Sigrist, 2009).

Invertebrate and waterfowl breeders were not included in the research due to the great irregularity in records caused by the lack of information of the breeders, who consider these species as domestic and did not fully disclose such information. The breeding of reptiles and amphibians has been prohibited in the country since 2002, and there only remains authorized breeders who were licensed prior to the IBAMA NI $n^{\circ} 31 / 02$. Therefore this survey did not include the Amphibia class.

\section{Results}

The number of wildlife breeders in Santa Catarina has been increasing considerably each year. Since 1996 when the first breeder was authorized until 2008, there was a significant increase $\left(\mathrm{R}^{2}=0.98 ; \mathrm{p}<0.001\right)$ in the number of breeders legalized in the state, with an average increase of six breeders per year (Figure 1). The survey showed that until the end of 2008, there were 79 breeders and 11 wildlife traders registered at IBAMA, distributed around 36 cities and present in all regions in the state of Santa Catarina.

The region that presented the largest number of wildlife breeders was Itajaí Valley, followed by Great Florianópolis (Table 1). Commercial breeding accounted for the highest number of breeders in Santa Catarina $(51 \%)$ and occurred in all regions of the state. Scientific breeding had the lowest number of breeders $(4.4 \%)$, and was present only in two regions: Itajaí Valley and Great

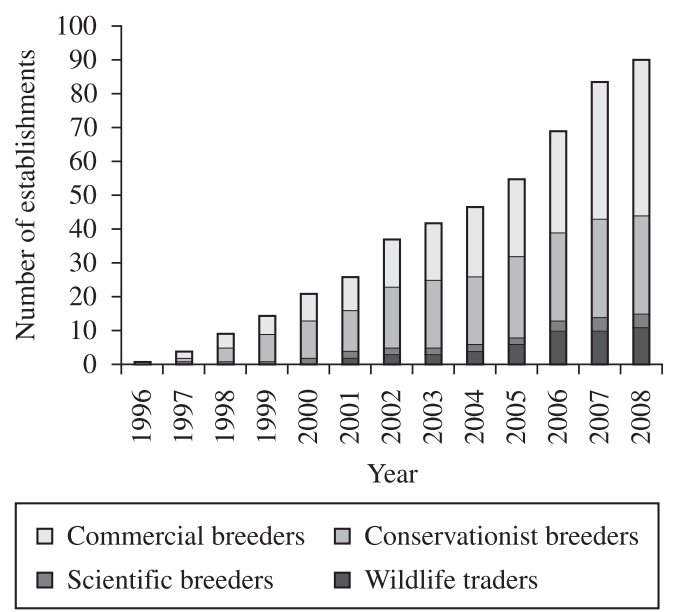

Figure 1. Number of registered wildlife breeders and traders in Santa Catarina state from 1996 to 2008.

Table 1. Number of wildlife breeders and traders for each region of Santa Catarina State.

\begin{tabular}{lccccc}
\hline \multicolumn{1}{c}{ Region } & $\begin{array}{c}\text { Commercial } \\
\text { breeder }\end{array}$ & $\begin{array}{c}\text { Conservationist } \\
\text { breeder }\end{array}$ & $\begin{array}{c}\text { Scientific } \\
\text { breeder }\end{array}$ & $\begin{array}{c}\text { Wildlife } \\
\text { trader }\end{array}$ & Total \\
\hline Itajaí Valley & 19 & 19 & 3 & 3 & 44 \\
Great Florianópolis & 11 & 6 & 1 & 7 & 25 \\
North & 6 & 4 & 0 & 0 & 10 \\
West & 5 & 0 & 0 & 1 & 6 \\
Sierra & 3 & 0 & 0 & 0 & 3 \\
South & 2 & 0 & 4 & 0 & 90 \\
Total & 46 & 29 & & & 11 \\
\hline
\end{tabular}


Florianópolis. Wildlife traders, represented by pet shops and food stores, do not occur in large numbers and are concentrated mainly in the capital.

In total, 213 species of wildlife are native to Santa Catarina and birds account for most ( $82 \%$, see Table 2$)$. The bird species bred are classified into 25 families belonging to 11 orders. However, $75 \%$ of these species belong to only two orders: Psittaciformes and Passeriformes. The most commonly bred species are Amazona aestiva (Linnaeus, 1758) bred by $37.5 \%$ of the commercial breeders, and Ara ararauna (Linnaeus, 1758) bred by $54.8 \%$ of the conservationist breeders. Both commercial breeders and conservationist breeders raise approximately the same number of bird species with a $59 \%$ similarity between the species bred. Curiously, there are no scientific establishments breeding birds.

The mammal species most commonly bred is Cuniculus paca (Linnaeus, 1766), bred mainly by the commercial breeders $(32.3 \%)$ for the purpose of human consumption. Between the 19 species of mammals bred, $47 \%$ belong to the order Artiodactyla and $26 \%$ belong to the order Primates - especially the family Callithrichidae, bred exclusively by the commercial breeders for sale as pets. The remaining species belong to four families of the orders Carnivora and Rodentia.

Reptile breeding represents only seven percent of wildlife breeding in Santa Catarina. Altogether there are 17 species belonging to nine families of only three orders. Snakes are the main species bred (76\%) especially by scientific breeders. The other species belong to the Crocodilia and Chelonia orders.

Among the 213 wild species bred in Santa Catarina, $48 \%$ are native to the state, $32 \%$ occur in other Brazilian states and $20 \%$ are exotic to Brazil. The conservation status of most of these species is classified by IUCN as Least Concern $(68 \%)$, however, nine percent $(n=18)$ of these species are vulnerable or endangered species (Figure 2) and more than half of these $(\mathrm{n}=10)$ are bred commercially. It is worth stating that among the species classified as vulnerable or endangered, all are birds. Of these species only five are exotic to Brazil, five other species are native to Santa Catarina and eight are native to other Brazilian states. None of the breeders raised species classified within the categories of Critically Endangered or Extinct.

The comparison between the number of species allowed to be bred and the number of species that have actually been bred, demonstrates the potential for an increase in overall wildlife breeding in Santa Catarina state. Currently, breeders are allowed to raise 988 species, however, only
213 (Table 2) are bred, meaning that the number of species currently raised could increase by $364 \%$. Such species are not currently being bred for different reasons such as the difficulty of obtaining breeding pairs, low demand by the consumer market, and even due to the fact that some breeders could be working with their full capacity.

Some breeders reported the breeding of species for which they were not authorized. In total, 93 species were bred illegally by 19 breeders (13 commercial, five conservationist and one scientific), and 32 of these species are not allowed to be bred by any category of breeder in the state. Between the species bred illegally, 48 are native to the state, 23 occur in other Brazilian states and 22 are exotic. Among native species of Santa Catarina, three are classified as vulnerable or endangered by the IUCN, they are: Amazona vinacea (Kuhl, 1820), Dryocopus galeatus (Temminck, 1822), Procnias nudicollis (Vieillot, 1817).

\section{Discussion}

The last survey of IBAMA in 2004 stated that Santa Catarina was responsible for $4 \%$ of wild animal breeding in Brazil (IBAMA, 2003, 2004a,b). Since then, the number of breeders and traders of wildlife has nearly doubled in the state, concentrated mainly in the regions of Itajaí Valley and Great Florianópolis. The concentration of breeders in these two regions can be related to population density and with the type of colonization that occurred in these areas. The Itajaí Valley and Great Florianópolis were colonized by

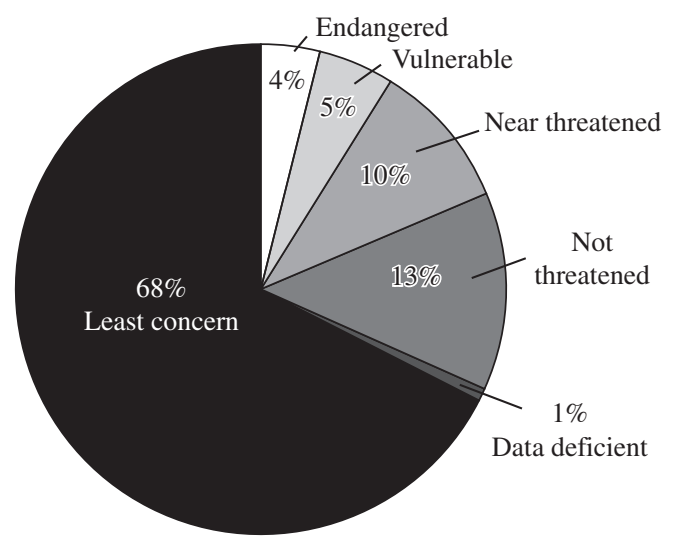

Figure 2. Percentage of the number of wildlife species bred in Santa Catarina state, by status of threat to extinction according to Red List Categories and Criteria of the International Union for Conservation of Nature (IUCN).

Table 2. Number of wild birds, mammals, and reptile species bred in Santa Catarina.

\begin{tabular}{|c|c|c|c|c|}
\hline \multirow{2}{*}{ Class } & \multicolumn{3}{|c|}{ Number of species per breeding category } & \multirow{2}{*}{$\begin{array}{c}\text { Total number } \\
\text { of species }\end{array}$} \\
\hline & Commercial & Conservationist & Scientific & \\
\hline Birds & 120 & 128 & 0 & 177 \\
\hline Mammals & 16 & 3 & 3 & 19 \\
\hline Reptiles & 1 & 8 & 10 & 17 \\
\hline Total & 137 & 139 & 13 & 213 \\
\hline
\end{tabular}


the Germans and the Azoreans, respectively, and breeding songbirds is part of both cultures.

Songbirds are a species commonly found in captivity in Brazil (Sick, 1997). In Santa Catarina state, the breeding of Passeriformes comes second only to the breeding of Psittaciformes. Parrots, due to their ability to imitate the human voice combined with their beauty, are the most popular and sought after birds as pets worldwide, after dogs and cats (Abramson et al., 1995; Sick, 1997).

The culture of breeding wild birds in Santa Catarina state is so significant that in addition to breeders described in this work there are more than 11,900 amateur songbird breeders registered in IBAMA, breeding about 117,000 birds of various species (Souza, 2004). The volume of wildlife breeding and sales in Santa Catarina raises questions about the conservation of these species. As well as being the most popular species legally bred, birds are also the most illegally trafficked in Brazil (RENCTAS, 2001). Only $5 \%$ of parrots sold in Brazil are captively bred and the remainder are removed illegally from the wild, because the reproduction of these animals is difficult and costly (RENCTAS, 2001). As a result, the parrots are the largest group of species listed in the Brazilian Fauna Threatened of Extinction (Sick, 1997).

The greatest conservation risks associated with the captive breeding of threatened or endangered species are when individual animals, or their parts and products, are of high value, while at the same time the animals are highly endangered in the wild (WWF, 2007). This becomes a larger issue if there is a high risk of poaching and illegal trade in wild individuals of the same species. In this context, the state of Santa Catarina deserves attention because beyond breeding endangered species commercially, it is also part of the route to wildlife trafficking.

Our study shows that most species bred in Santa Catarina do not belong to threatened or vulnerable species. However, it should be noted that this classification was based on the IUCN red list categories and criteria, which takes into account the global distribution of species. Often a species that is not threatened with extinction on a world scale may be at high risk of extinction on a local scale.

The fact that $52 \%$ of the wildlife bred currently in Santa Catarina is exotic to Brazil or are native to other Brazilian states, can be a threat to local biodiversity. There are countless examples of negative impacts on nature due to the introduction and establishment of exotic species because of unsuccessful breeding containment. An example in Santa Catarina state is the invasion of the exotic species Sus scrofa (Linnaeus, 1758) (wild boar) that has already caused many ecological, economic and health problems (Salvador et al., 2009).

The conservation and welfare risks due to the remarkable growth of wild animal breeding in captivity, is related to the difficulties faced by the responsible office to carry out the management of this activity. While the number of breeders in the state has doubled over the last decade, the number of officials responsible for licensing and inspection of breeding sites remained two people. These officials are not only responsible for the management of these breeders, but also for licensing and inspection of six zoos and about 12,000 amateur breeders of songbirds in the state, besides other bureaucratic functions required for the position.

The difficulties faced by the responsible office to supervise the breeders' activities are further made difficult by the quality of reports submitted by the breeders to IBAMA. Many contain inaccurate data, incomplete or dubious information. Only a few breeders forward their annual reports regularly. In most cases, the breeders' reports were late or not submitted for years. Completing the reports with only the common name of the species is another regular practice among breeders and which makes the interpretation of the information presented very difficult. Taxonomic classification errors and inconsistent information were also seen in Southeast Asia and the USA (Blundell and Mascia, 2005).

Another irregularity detected in some of the reports was that some species were being bred without a license. Although there is no direct relationship between these irregularities and the trafficking of these specimens, the fact that there is illegal breeding in Santa Catarina of endemic and endangered species is relevant. To ensure that legal trade does not become a facilitator for wildlife trafficking, it is necessary that more oversight and inspections occur to ensure that natural populations will not be affected.

The creation of Sisfauna certainly represents an advance in wildlife management in Brazil and also helps to combat illegal wildlife breeding. However, it is only an administrative advancement until now and there is still a requirement to increase the effective supervision and personnel for combating irregularities related to the welfare of animals and illegal trade. Currently, the irregularities related to wildlife are monitored by IBAMA in conjunction with the police and both agencies are struggling with low numbers of employees, the lack of vehicles and fuel for the inspections, and the need of infrastructure to allocate the animals seized.

Many advances have been achieved by changes in Brazilian legislation, but more investment from the government for managing and monitoring wildlife trade in Brazil is still required. Given the magnitude of the wildlife trade and the impacts on conservation, more research must be done on the trade of wildlife, thereby helping to manage and supervise this activity. Survey data on wildlife trade is essential to generate knowledge for decision making and to promote alternatives between socioeconomic and conservationists interests. We hope that the data presented in this paper contributes to the development of conservation strategies and conscious use of Brazilian wildlife resources.

Acknowledgements - We would like to thank the officials of NUFAP/IBAMA/SC who gave us the opportunity and support to carry out this research, especially Edinéia Caldas Correa and Hélio Bustamante Pereira de Sá. We would also like to thank Sara Dubois from the Animal Welfare Program of the University of British Columbia for improving the manuscript. Thank you to Tracy Burnett and Karen Burk for translating the article. 


\section{References}

Abramson, J., Speer, BL. and Thompen, JB., 1995. The large macaws: their care, breeding and conservation. California: Raintree Publications. 552 p.

BLUNDELL, AG. and MASCIA, MB., 2005. Discrepancies in reported revels of international wildlife trade. Conservation Biology, vol. 19, no. 6, p. 2020-2025. http://dx.doi.org/10.1111/j.15231739.2005.00253.x

CARRETE, M. and TELLA, JL., 2008. Wild-bird trade and exotic invasions: a new link of conservation concern? Frontiers in Ecology and Environment, vol. 6, no. 4, p. 207-211. http:// dx.doi.org/10.1890/070075

GILARDI, D., 2006. Captured for conservation: will cages save wild birds? A response to Cooney \& Jepson James. Oryx, vol. 40, no. 1, p. 24-26.

GONÇALVES, MLQ. and REGALADO, LB., 2007. A relação entre o homem e o animal silvestre como uma questão de educação ambiental. Fórum ambiental da alta paulista, vol. 3, p. 309-330.

Instituto Brasileiro de Geografia e Estatística - IBGE, 2007. Santa Catarina. Available from: <http://www.ibge.gov.br/estadosat/ perfil.php?sigla=sc >. Access in: out. 2009.

Instituto Brasileiro do Meio Ambiente - IBAMA, 2003. Lista dos criadores científicos. Available from: <http://www.ibama. gov.br/fauna/criadouros/cientificos.pdf> Access in: set. 2009.

-, 2004a. Lista dos criadores conservacionistas. Available from: $<$ http://www.ibama.gov.br/fauna/criadouros/conservacionistas. pdf>. Access in: set. 2009.
-, 2004b. Lista dos criadores comerciais. Available from: <http:// www.ibama.gov.br/fauna/criadouros/comerciais.pdf $>$. Access in: set. 2009.

Internacional Union for Conservation of Nature and Natural Resources - IUCN, 2009. IUCN Red List of Threatened Animals. Available from: <http://www.iucnredlist.org/>. Access in: set. 2009.

KLEIN, RM., 1978. Mapa fitogeográfico do Estado de Santa Catarina. Flora Ilustrada Catarinense, vol. 5, p. 1-24.

Rede Nacional de Combate ao Tráfico de Animais Silvestres RENCTAS, 2001. Primeiro relatório nacional sobre o tráfico da fauna silvestre. Available from: <http://www.renctas.org.br/files/ REL_RENCTAS_pt_final.pdf>. Access in: set. 2009.

-, 2002. Animais silvestres: vida à venda. Brasília: Dupligráfica. 220 p.

SALVADOR, CHO., OLIVEIRA-SANTOS, LG. and FERNANDEZ, FAS., 2009 Abundance and invasion risk of wild boars, Sus scrofa scrofa (Artiodactyla:Suidae), in Araucaria Forest, Brazil. In Annals of the $10^{T H}$ Mammalogical Congress, 2009. Mendoza: IFM.

SICK, H., 1997. Ornitologia brasileira. Rio de Janeiro: Nova Fronteira. $912 \mathrm{p}$

SIGRIST, T., 2009. Guia de campo: Avifauna Brasileira. São Paulo: Avis Brasilis. 480 p.

SOUZA, I., 2004. A criação da fauna silvestre em Santa Catarina: dos agroecossistemas indígenas aos dias atuais. Florianópolis: Universidade Federal de Santa Catarina. Dissertação de Mestrado em Agroecossistemas.

World Wildlife Founding - WWF, 2007. Policy statement on captive breeding. Available from: <http://wwf.panda.org/ about_our_earth/all_publications/?103860/Captive-BreedingWWF-Policy-Statement-2007>. Access in: out. 2009. 